\title{
A felnőttkori krónikus köhögés ellátása a mindennapi gyakorlatban
}

\author{
Szalai Zsuzsanna dr. \\ Petz Aladár Megyei Oktató Kórház, Pulmonológiai Osztály, Győr
}

\begin{abstract}
A köhögés miatt orvoshoz forduló betegek száma jelentős. A krónikus köhögés - amely definíció szerint 8 hétnél hosszabb ideig tart, és amelynek hátterében nem igazolható sem kóros radiológiai elváltozás, sem külső inhalatív ártalom, például dohányzás - leggyakoribb okai a felső légúti köhögés szindróma, az asztma, a refluxbetegség és a gyógyszer (ACE-gátló)-mellékhatás. A szerző a közleményben összefoglalja a kórképekkel kapcsolatos legújabb szakmai ajánlásokat, az oki kezelést, és rövid kitekintést nyújt a tünetei kezelés lehetőségeire.
\end{abstract}

Orv Hetil. 2020; 161(40): 1707-1710.

Kulcsszavak: krónikus köhögés, asztma, felső légúti köhögés szindróma, reflux, inhalációs szteroid

\begin{abstract}
Management of chronic cough in adults
The number of patients who seek medical attention for cough is high. Chronic cough is defined to last longer than 8 weeks. After excluding inhalativ harm, e.g., smoking, and there is no abnormal radiologic lesion, the most common causes are upper respiratory cough syndrome, asthma, gastro-oesophageal reflux, post-infectious cough, iatrogenic cough (most commonly induced by ACE inhibitors) and some less frequent diseases. The author summarizes the most recent professional recommendations for investigation, causal treatment, and provides a brief overview of the symptome treatment options.
\end{abstract}

Keywords: chronic cough, asthma, upper respiratory cough syndrome, reflux, inhaled corticosteroids

Szalai Zs. [Management of chronic cough in adults]. Orv Hetil. 2020; 161(40): 1707-1710.

(Beérkezett: 2019. december 13.; elfogadva: 2020. február 5.)

\begin{abstract}
Rövidítések
$\mathrm{ACE}=($ angiotensin-converting enzyme $)$ angiontenzinkonvertáló enzim; ACEI = ACE-inhibitor; $\mathrm{ARB}=$ angiotenzinreceptor-blokkoló; ATP = adenozin-trifoszfát; COPD = (chronic obstructive pulmonary disease) krónikus obstruktív tüdőbetegség; CT = (computed tomography) számítógépes tomográfia; $\mathrm{CVA}=($ cough variant asthma $)$ asztma köhögéses variánsa; GERD $=($ gastroesophageal reflux disease $)$ gastrooesophagealis refluxbetegség; H2-antagonista = hisztamin-2-receptor-antagonista; ICS = (inhaled corticosteroids) inhalációs szteroidok; $\mathrm{LPR}=$ (laryngo-pharyngeal reflux) laryngopharyngealis reflux; NERD $=$ (nonerosive reflux disease $)$ nem erozív refluxbetegség; $\mathrm{NO}=$ nitrogén-monoxid; PPI = protonpumpa-inhibitor; RCC $=$ (refractory chronic cough) terápiarezisztens krónikus köhögés; UACS = (upper airway cough syndrome) felső légúti köhögés szindróma; UCC = (unexplained chronic cough $)$ ismeretlen eredetű krónikus köhögés
\end{abstract}

A köhögés egy védőreflex, amely megelőzi az aspirációt, és fokozza a légúti váladéktisztítást. Az életminőséget hátrányosan befolyásoló elhúzódó köhögés a felnőtt populáció 5-10\%-át érintheti [1]. Hátterében számos környezeti ártalom és betegség állhat. A dohányzás következtében kialakuló köhögés hátterében a leggyakrabban krónikus hörghurut, COPD, tüdő- és fej-nyaki daganat, ritkábban dohányzással összefüggő interszticiális tüdőbetegség és szívelégtelenség áll. A szerves és szervetlen porok inhalálása kapcsán kialakuló tüdőparenchyma betegségei, az infektív vagy egyéb eredettel kialakuló bronchiectasia, továbbá a radiológiai árnyékot okozó daganatos, gyulladásos vagy genetikai eredetű betegségek és idősekben az aspiráció is okai lehetnek a köhögésnek. A felsorolt tüdőgyógyászati vagy gégészeti kórképek részletezése nem képezi tárgyát ennek a közleménynek. 
Az excesszív köhögéssel kapcsolatos pszichés (kimerülés, kancerofóbia, szorongás) és szociális terhek (nehezített beszéd, incontinentia, a közösségi eseményeken való részvétel ellehetetlenülése) miatt a betegek nagy többsége viszonylag korán orvoshoz fordul. Az első orvos-be-

1. táblázat |A felnőttkori krónikus köhögés kivizsgálási javaslata, az ERS szakmai ajánlása [2] alapján

Az anamnézis felvétele és fizikális vizsgálat

- Előző betegségek, gyógyszerszedés

- Családi anamnézis

- A köhögés időtartama, jellege

- Köhögést kiváltó ingerek, napszaki ingadozás

- Külső inhalatív ártalom: dohányzás, munkahelyi ártalom, hobbi

- Fizikális vizsgálat: kiemelten a garat-gége-orr és a tüdó

Rutinvizsgálatok

- Mellkasröntgen

- Spirometria

Terápiarezisztens esetben a szakorvosi ellátásba tartozó kiegészító vizsgálatok

- Fül-orr-gégészeti vizsgálat, laringoszkópia

- Tüdőgyógyászati vizsgálat, kibővített légzésfunkciós vizsgálat, köpet/vér eozinofil szint, HRCT, bronchoszkópia, FeNo-mérés - Gasztroenterológiai kivizsgálás, oesophagusmanometria

ERS = Európai Tüdőgyógyász Társaság; FeNO = frakcionált kilélegzett nitrogén-monoxid; HRCT = magas felbontású komputertomográfia

2. táblázat

A felnőttkori krónikus köhögés hátterében álló leggyakoribb kórképek és azok kezelése, az ERS szakmai ajánlása [2] nyomán. A beteg részletes kikérdezése kiemelt fontossággal bír. A felsorolt tünetekre egyenként is javasolt rákérdezni, mivel azokat a betegek spontán nem szokták megemlíteni, vagy csak azt emelik ki, amit fontosnak vélnek

\begin{tabular}{|c|c|}
\hline A krónikus köhögést kísérő tünetek & Elsődleges ellátás \\
\hline \multicolumn{2}{|l|}{ Felső légúti köhögés szindróma } \\
\hline $\begin{array}{l}\text { Orrdugulás, orrfolyás, garatcsorgás, torokfájás, } \\
\text { torokköszörülés, orr- és garatviszketés, } \\
\text { ödémacsökkentő orrcsepp abúzus }\end{array}$ & Nazális szteroid \\
\hline \multicolumn{2}{|l|}{ Asztmavariánsok } \\
\hline $\begin{array}{l}\text { Mellkasfeszülés, mellkasi nyomásérzés, mellkasi } \\
\text { diszkomfort, sípoló légzés, mellkasfájdalom, a } \\
\text { köhögés fokozódása külső ingerekre (füst, köd, } \\
\text { hideg, fizikai terhelés, nevetés, sírás), éjszakai } \\
\text { köhögés, ismert légúti allergia; a tünetek } \\
\text { gyakran rohamszerúen lépnek fel }\end{array}$ & $\begin{array}{l}\text { Kis dózisú } \\
\text { inhalációs } \\
\text { szteroid, esetleg } \\
\text { leukotriénantago- } \\
\text { nista }\end{array}$ \\
\hline \multicolumn{2}{|l|}{ Refluxköhögés } \\
\hline $\begin{array}{l}\text { Gyomorégés, maró érzés a nyelőcsőben vagy a } \\
\text { garatban, savas felböfögés, regurgitatio, reggeli } \\
\text { rekedtség, rossz szájíz, rossz szájszag, } \\
\text { fogszuvasodás }\end{array}$ & PPI \\
\hline \multicolumn{2}{|l|}{ Gyógyszermellékhatás } \\
\hline $\begin{array}{l}\text { ACE-gátló-szedés kezdetétől egy hét és } 6 \\
\text { hónap között alakul ki a leginkább, nőknél } \\
\text { gyakoribb, csiklandó érzéssel járhat }\end{array}$ & $\begin{array}{l}\text { ACE-gátló } \\
\text { használatának } \\
\text { a revíziója, } \\
\text { terápiaváltás }\end{array}$ \\
\hline
\end{tabular}

ACE = angiontenzinkonvertáló enzim; ERS = Európai Tüdőgyógyász Társaság; PPI = protonpumpa-inhibitor teg találkozáskor, az anamnézisfelvételt követően a külső környezeti ártalmak vagy a kóros radiológiai eltéréssel járó kórképek gyorsan kiderülnek, és a beteg a szakorvosi ellátásba kerül. A felsoroltak kizárása után szokott sor kerülni az empirikusan adott kezelésekre, amelyeket a háziorvos - nagyon helyesen - leginkább az anamnézisfelvételkor kapott adatokra és tünetekre alapoz. Előfordul azonban, hogy a nem megfelelően interpretált vagy hiányos információk fölösleges vizsgálatokhoz és eredménytelen kezelésekhez vezetnek, ami hosszú távon elégedetlenné teszi a beteget, és frusztrálni fogja a kezelőorvost. A leggyakrabban arra látunk példát, hogy a krónikusan köhögő betegnél hamarabb történik meg az antihipertenzív gyógyszer cseréje vagy a gyomortükrözés, mintsem kezelést kapna eldugult orrára, vagy felmerülne az asztma lehetősége. Gyakran történik fölösleges mellkas-CT is, pedig a szakmai ajánlások egyértelmúen kimondják, hogy a krónikus köhögés miatt végzett mellkasröntgen negativitása esetén a mellkas-CT-től további információ nem várható.

A jelen közlemény - felhasználva a legújabb szakmai guideline-okat $[2,3]$ és figyelembe véve a hazai szokásokat - a krónikus köhögés leggyakoribb okait és a kezelés lehetőségeit foglalja össze, elsősorban háziorvos kollégák részére. Ugyanez röviden áttekinthető az 1 . és a 2. táblázatban.

\section{A krónikus köhögés és a hátterében álló leggyakoribb kórképek}

A három hétnél hosszabb ideig fennálló köhögést szubakutnak, a nyolc hétnél hosszabb ideig tartót pedig krónikus köhögésnek nevezzük. A tünettel orvoshoz fordulók kétharmada nő, aminek ismert élettani okai vannak. Nőkben a köhögési inger kifejezettebb, a háttérben a terhesség alatti aspirációhajlam miatti fokozott védelmi rendszer áll. Az elhúzódó köhögéssel jelentkező nők életkori csúcsa az ötvenes-hatvanas éveik közé tehető [4]. A krónikus köhögés hátterében 80-90\%-ban néhány jól ismert kórkép azonosítható $[2,3]$ : felső légúti köhögés szindróma, különböző asztmavariánsok, gastrooesophagealis reflux és jatrogén (a leggyakrabban ACEgátlók által indukált) ártalom, amelyek zöme a háziorvosi rendelésen ellátható. Amennyiben diagnosztikus és terápiás erőfeszítéseink nem hoznak eredményt, igazi „idiopátiás” vagy „terápiarezisztens” köhögésről beszélünk, amelynek kezelése ma sincs megoldva.

\section{Felső légúti köhögés szindróma}

Az elhúzódó köhögés leggyakoribb oka az UACS (upper airway cough syndrome), vagyis a krónikus felső légúti betegségeket kísérő köhögés, korábbi nevén garatcsorgás, ún. „postnasal drip”. Hátterében krónikus allergiás és nem allergiás, vasomotoros és jatrogén rhinitis, krónikus sinusitis, septumdeviáció, orrpolyposis állhat. Króni- 
kus orrdugulás, orrfolyás, torokköszörülés, torokfájás utal erre a kórképre, de előfordulhat az is, hogy csak a köhögés áll fenn. Az orrgarat megtekintésével láthatóvá válik a hátsó garatcsorgás vagy a nasopharynx gyulladása.

A magas evidenciájú szakmai ajánlások alapján a felsó légúti köhögés szindróma kezelésére nazális szteroid ajánlott [3]. A tünetek néhány nap alatt javulnak, a maximális terápiás eredmény eléréséhez viszont több hét kezelésre is szükség lehet, és ezt a betegnek el kell magyarázni. Az ödémacsökkentő orrcseppek tartós használatát fel kell függeszteni. A hozzászokás megszüntetésének is hatékony módja a helyileg alkalmazott szteroid. Allergiás nátha esetén célszerü kombinált (lokális szteroidot és antihisztamint is tartalmazó) orrsprayt adni. Bár allergiás náthában az orális antihisztaminok is hatásosak lehetnek - de az első generációs készítmények szedációt okozó mellékhatásai miatt nem javasoltak -, amennyiben orrdugulás is fennáll, a lokális, szteroidtartalmú készítményeket részesítjük előnyben.

\section{Asztmás köhögés}

A felnőttkori krónikus köhögés hátterében álló második leggyakoribb ok az asztma. Az asztma egy klinikai diagnózis, mert nincs olyan vizsgálati módszerünk, amellyel teljes biztonsággal lehetne igazolni vagy kizárni a betegséget. A mélyben zajló eozinofil gyulladás kimutatására a köpet eozinofilvizsgálata, a NO-kilégzési teszt vagy a kevésbé megbízható szérumeozinofília (300 sejt/ $\mu l$ felett) alkalmas, ezeket azonban a mindennapi gyakorlatban nem használjuk. Ezért az anamnézisfelvétel, valamint a tünetek részletes kikérdezése és értelmezése különösen fontos. Könnyű felállítani a diagnózist egy köhögő atópiás (ekcémás, allergiás, szénanáthás) beteg esetében, fóként, ha a köhögés mellett sípoló légzésről, mellkasfeszülésről és éjszakai fulladásos rohamokról is beszámol. Ez az ún. „klasszikus asztma”, amelyet a spirometriás vizsgálatokkal mért légúti variabilitás és hiperreaktivitás jellemez. Előfordulhat azonban, hogy az asztma kizárólag köhögésben nyilvánul meg, ez az ún. „asztma köhögéses variánsa” (CVA - cough variant asthma). Jellemzően felső légúti vírusinfekció után alakul ki, mintegy „posztinfekciós köhögés” asztmavariánsaként. Ennek igazolására használhatók ugyan a felsorolt módszerek, de a legfontosabb itt is a beteg pontos kikérdezése, valamint az antiasztmatikus terápiára adott gyors kedvező válasz. A krónikus köhögés hátterében ismert harmadik asztmavariáns az ún. „eozinofil bronchitis”, amelyben nincs ugyan légúti hiperreaktivitás vagy bronchospasmus, de köpetvizsgálattal igazolható az eozinofil gyulladás.

A három asztmavariáns mindegyikére igaz, hogy eredményesen kezelhetők inhalációs szteroidokkal (ICS) [2]. $\mathrm{Az}$ elhúzódó száraz köhögés hátterében feltételezett asztma kezelésére alacsony dózisú, inhalációs szteroiddal végzett 2-4 hetes terápiás próba javasolt. Mivel a szakorvosi előjegyzés többhetes, a kezelés háziorvosi praxisban is elkezdhető. Az ICS hatására az asztmás köhögés gyor- san javul, és néhány hét alatt teljesen meg is szúnik. A leukotriénantagonistákkal (montelukaszt) is lehet terápiás próbát végezni, bár az eredmények ellentmondásosak [2]. Bármelyik készítményt adjuk, eredményes kezelés esetén is javasolt a beteget szakorvoshoz irányítani, mert csak további kivizsgálás és gondozás során lehet dönteni a későbbi fenntartó kezelés szükségességérôl, a hatóanyagdózisokról és a kiegészítő gyógyszerekről.

\section{Refluxköhögés}

A krónikus köhögés harmadik leggyakoribb oka, amelynek hátterében nemcsak a gastrooesophagealis (GERD, NERD) és a laryngopharyngealis reflux (LPR), hanem az oesophagealis dysmotilitas és a krónikus aspiráció szerepe is igazolható. A laryngopharyngealis reflux során a gyomortartalom a garat/gége területére jut: ilyenkor a betegeknek alig egyharmada panaszol gyomorégést, gyakoribb a diszfónia, a rekedtség, a torokköszörülés, a köhögés és ritkábban az enyhe nyelészavar. Gégészeti vizsgálat során az arytenoid erythema és a garat gyulladása utal a betegségre. Ez esetben is a legfontosabb a beteg tüneteinek pontos ismerete, miszerint van-e maró érzés a nyelőcsőben vagy a garatban, savas felböfögés, regurgitatio, reggeli rekedtség, gyomorégés, rossz szájíz, rossz szájszag, fogszuvasodás.

Krónikus köhögés esetén - amennyiben az esetleges reflux csak feltételezés, és típusos tünetek nem kísérik az új ajánlások nem javasolják a savcsökkentők rutinszerü alkalmazását. Metaanalízisek során nem találtak bizonyítékot arra, hogy a savcsökkentők (PPI vagy H2-antagonisták) megszüntetnék a gyomorégéssel vagy refluxos tünetekkel nem járó köhögést [5]. Ezért PPI vagy H2antagonista alkalmazása krónikus köhögésre csak abban az esetben javasolt, ha a beteg tényleg beszámol a fenti tünetekről, és/vagy a vizsgálatok is azt igazolják. A promotilitási aktivitással rendelkező gyógyszerek (metoklopramid, domperidon, baklofén) használata ugyancsak igazolt motilitási zavarok esetén jön szóba. Az életmódbeli tanácsok csökkentik vagy megelőzik a reflux kialakulását, ezek közé tartozik a testsúlycsökkentés, az ágy fejrészének megemelése, a dohányzás elhagyása, refluxot okozó élelmiszerek (alkohol, csokoládé, zsíros ételek, narancslé stb.) kerülése, különösen a lefekvés előtti 2-3 órában. Az antirefluxmütétek megítélése továbbra is ellentmondásos.

\section{ACE-gátlók}

A kezelt betegek átlag 15\%-ánál alakul ki köhögés [3]. Bár a patogenezis nem ismert pontosan, a leegyszerúsített feltételezés az, hogy az ACE-inhibitorok meggátolják a légutakban a protusszív bradikinin és a P-anyag lebomlását, amelyek felszaporodnak, és stimulálják a köhögésért felelős afferens C-rostokat. Az ACE-gátló mellékhatásaként kialakuló köhögés jellemzői: a kezelés kezdetétől számított egy hét és 6 hónap között alakul ki, 
„csiklandó” inger jellemzi, gyakrabban fordul elő nőknél, nem függ össze az asztmás hajlammal, és a gyógyszer elhagyásával megszúnik. Az ACEI visszaadására újra fellép, de ARB-re váltáskor nem.

\section{Tüneti kezelés}

Minden diagnosztikus erőfeszítésünk mellett is előfordul, hogy nem sikerül igazolni a krónikus köhögés okát (UCC - unexplained chronic cough), és ismert ok mellett is elöfordul terápiarezisztens köhögés ( $\mathrm{RCC}$ - refractory chronic cough). Ez esetekben jönnek szóba a tüneti, leggyakrabban a neuromodulátori hatással bíró terápiák, mint az opiátok, a gabapentin vagy a P2X3-antagonisták. Terápiarezisztens és az életminőséget súlyosan rontó köhögés esetén a nemzetközi ajánlások [2] a kis dózisú (napi $2 \times 5-10 \mathrm{mg}$ ), elhúzódó hatású morfinszármazék adását javasolják. Mellékhatásként székrekedéssel, álmossággal kell számolni. Alternatívája lehet a gabapentin (maximum $1800 \mathrm{mg}$ naponta) vagy a pregabalin (300 mg naponta). Szédülés, gyengeség, hányinger, homályos látás a gyakori mellékhatások, emiatt gyakran fel kell függeszteni a kezelést. Célszerű ezeket beszédterápiával kiegészíteni, bár az ebben járatos logopédus elérhetősége meglehetősen behatárolt. A kifejlesztés alatt álló, jövőbeli terápiás lehetőségek nem túl szélesek, a P-anyag-antagonista orvepitant mérsékelt hatást, az ATP által aktivált P2X3-purinergreceptor-antagonista gefapixant viszont drámai javulást mutatott a krónikus köhögés kezelésében; a klinikai vizsgálatok még folyamatban vannak [2].

\section{Következtetés}

A nyolc héten túl fennálló krónikus köhögés hátterében - amennyiben kizárjuk a külső inhalatív noxákat, az infekciót és a kóros radiológiai elváltozással járó kórképeket - gyakorisági sorrendben a felső légúti köhögés szindróma, az asztma, a refluxbetegség és az ACE-gátlómellékhatás áll. A diagnózis felállításának legfontosabb sarokköve az anamnézis pontos felvétele és a tünetek részletes kikérdezése. Mindezek ismeretében a háziorvosi praxisban felállítható az a munkadiagnózis, amely alapján elkezdhető a célzott kezelés. Felső légúti köhögés szindróma esetén nazális szteroid, asztma esetén inhalációs szteroid, egyértelmű refluxos tünetek fennállása esetén savcsökkentés, ACE-gátló mellett kialakult köhögés esetén annak felfüggesztése javasolt. A terápia eredményessége, valamint a kórlefolyás alapján dönt a kezelőorvos a további szakorvosi referálás szükségességéről. A viszonylag ritkán előforduló terápiarezisztens krónikus köhögés esetében multidiszciplináris kivizsgálás, valamint tüneti kezelés jön szóba.

Anyagi támogatás: A szerző a cikk elkészítéséért anyagi támogatásban részesül a Sager Pharma Kft.-től.

A szerző a cikk végleges változatát elolvasta és jóváhagyta.

Érdekeltségek: A cikkel kapcsolatban a szerzőnek nincsenek érdekeltségei.

\section{Irodalom}

[1] Song WJ, Chang YS, Faruqi S, et al. The global epidemiology of chronic cough in adults: a systematic review and meta-analysis. Eur Respir J. 2015; 45: 1479-1481.

[2] Morice AH, Millqvist E, Bieksiene K, et al. ERS guidelines on the diagnosis and treatment of chronic cough in adults and children. Eur Respir J. 2020; 55: 1901136.

[3] Weinberger SE, Silvestri RC. Treatment of subacute and chronic cough in adults. UpToDate Inc. Available from: https://www. uptodate.com/contents/treatment-of-subacute-and-chroniccough-in-adults [accessed: December 8, 2019].

[4] Millqvist E. The airway sensory hyperreactivity syndrome. Pulm Pharmacol Ther. 2011; 24: 263-266.

[5] Kahrilas PJ, Howden CW, Hughes N, et al. Response of chronic cough to acid-suppressive therapy in patients with gastroesophageal reflux disease. Chest 2013; 143: 605-612.

(Szalai Zsuzsanna dr., Gyơr , Vasvári Pál u. 2-4., 9024 e-mail: drszalaizs@gmail.com)

A cikk a Creative Commons Attribution 4.0 International License (https://creativecommons.org/licenses/by/4.0/) feltételei szerint publikált Open Access közlemény, melynek szellemében a cikk bármilyen médiumban szabadon felhasználható, megosztható és újraközölhető, feltéve, hogy az eredeti szerző és a közlés helye, illetve a CC License linkje és az esetlegesen végrehajtott módosítások feltüntetésre kerülnek. (SID_1) 